\title{
Uruguayan mortuaries and the No Names: the long story of the unidentified bodies found on the coastline of Uruguay during the Condor Plan
}

\begin{abstract}
Magdalena Figueredo and Fabiana Larrobla Facultad de Humanidades y Ciencias de la Educación. Universidad de la República
\end{abstract}

magdalenafigueredo@gmail.com, fabianalarro@gmail.com

\begin{abstract}
Between 1975 and 1979, thirty-one unidentified bodies bearing marks of torture appeared at various locations along Uruguay's coastline. These bodies were material proof of the death flights implemented in neighbouring Argentina after the military coup. In Uruguay, in a general context of political crisis, the appearance of these anonymous cadavers first generated local terror and was then rapidly transformed into a traumatic event at the national level. This article focuses on the various reports established by Uruguayan police and mortuary services. It aims to show how the administrative and funeral treatments given at that time to the dead bodies, buried anonymously (under the NN label) in local cemeteries, make visible some of the multiple complicities between the Uruguayan and Argentinean dictatorships in the broader framework of the Condor Plan. The repressive strategy implemented in Argentina through torture and forced disappearance was indeed echoed by the bureaucratic repressive strategy implemented in Uruguay through incomplete and false reports, aiming to make the $\mathrm{NN}$ disappear once again.
\end{abstract}

Key words: political violence, state repression, Condor Plan, NN, death flights

Between 1975 and 1979, ${ }^{1}$ thirty-one unidentified bodies appeared at various locations along Uruguay's coastline, of which more than half were discovered in 1976. That year marked a turning point in the evolution of authoritarian rule in Latin America. Argentina was entering one of the darkest periods of its history as the most heinous methods of repression were made manifest, while Uruguay, now a fully fledged dictatorship, was intensifying its authoritarian practices. Both states, galvanised by Operation Condor, were working to further entrench the machinery of their regimes in the Southern Cone.

It was against this backdrop that nine bodies were found in the department of Colonia and a further six in Rocha. Kept in local mortuaries, these bodies prompted persistent questions about their provenance. These were echoed by the press, particularly in Argentina, where there was speculation that the bodies might belong to civilians abducted as part of the military government's crackdown on 
political dissidents. This article will focus on these discoveries, arguing that they offer an insight into the institutional practices followed at that time - practices that reveal the web of complicity built up between Argentina and Uruguay. At the same time, they provide an opportunity to answer questions about where the bodies came from, what happened to them and, finally, who the so-called 'No Names' really were.

Existing scholarship in this area has not extended, in Uruguay at least, to any in-depth studies of these incidents, although they do receive some mention in the work of José López Mazz. In a chapter of a book edited by Funari and Aarankin (2006), entitled Una Mirada arqueológica a la represión en Uruguay (1971-1985), ${ }^{3}$ Mazz dedicates a section to 'tombs and skeletal remains', in which he refers to studies carried out by the Argentine Forensic Anthropology Team (EAAF, in Spanish) in Rocha and Colonia. Another article, 'The Concealment of Bodies during the Military Dictatorship in Uruguay (1973-84)'4 includes accounts of the mechanisms by which the bodies of the NN came to appear on Uruguay's shores, and the response of the authorities once these discoveries became known. But still, little is known about the trajectories of these bodies.

\section{The death flights}

On 27 June 1973 the government of Uruguay was overthrown in a coup d'état. Almost three years later, on 24 March 1976, similar events led to the establishment of the military dictatorship in Argentina. Both countries thereby aligned themselves with the new authoritarian logic that was gathering strength in Latin America, setting out - like Chile, Brazil and Paraguay - on a political trajectory underpinned by a clandestine system of repression.

Each state, propelled by its own dynamic, rolled out and consolidated a series of mechanisms based on the control, monitoring, surveillance and suppression of the civilian population, employing state violence to silence opponents and overcome resistance. In Uruguay the state became a master of illegitimate detention, making particularly extensive use of prolonged imprisonment, while Argentina followed a strategy aimed at annihilating those deemed to be enemies of the regime, disposing of their bodies in secret so that they would never be found.

These techniques of repression, which extended also to spreading fear among the population, weaving silence and secrecy into the fabric of everyday life, were suddenly made visible by the discoveries of the unidentified bodies which bore the physical signs of the horrors to which they had been subjected. Furthermore, they revealed the extent to which the Uruguayan dictatorship was complicit in these actions, taking every possible measure to misrepresent the provenance of the bodies and to cover up the truths that they threatened to expose.

State repression and violence, secrecy and dissimulation were the mainspring for a fluid channel of communication between the two regimes. This dialogue allowed crimes to be committed and left purposefully unresolved, information to be manipulated and, if need be, documentation relating to the deaths of civilians to be falsified. 


\section{Magdalena Figueredo and Fabiana Larrobla}

In 1977, with bodies continuing to appear, Argentine writer Rodolfo Walsh ${ }^{5}$ wrote a letter to the military junta containing an early denunciation of what have come to be known as the 'death flights':

Twenty-five mutilated bodies were washed up along the Uruguayan coastline between March and October 1976; a fraction, perhaps, of the victims tortured to death in the Naval Mechanics School and cast into the depths of the Río de la Plata from the Navy's own ships. Among them was a fifteen-year-old boy, Floreal Avellaneda, ${ }^{6}$ who had been bound by the hands and feet and whose body revealed evidence of 'injuries to the anal area and visible fractures,' according to the autopsy report. $^{7}$

The truth of these allegations was confirmed only years later, in 1995, when Horacio Verbitsky ${ }^{8}$ made public the confession of a retired navy officer, Adolfo Francisco Scilingo, in his book El Vuelo (The Flight). In this account, Scilingo gives a detailed description of the flights operated by the Argentine Armed Forces, during which prisoners were thrown, still alive, into the waters of the Río de la Plata.

The book also contains the text of a letter written by Scilingo to Jorge Videla on 26 February 1991:

In 1977, I was a naval lieutenant assigned to the Navy Mechanics School [known as the ESMA], operating under the supervision of the First Army Corps, and you were the General Commander of the Army. Acting under orders from the government's executive authority, represented by you, I took part in two transport flights. The first involved thirteen dissidents who were boarded onto a Skyvan belonging to the Naval Prefecture [Argentina's naval police force]. The second flight involved seventeen terrorists and an Electra belonging to the Naval Aviation Force. The prisoners were told that they were being evacuated to a penal facility in the south, and so were required to be vaccinated. They were given a first dose of anaesthetic, which would be reinforced by a second, larger dose once they were in the air. Finally, in both cases, the prisoners were thrown naked from the aircraft into the waters of the Southern Atlantic, in mid-flight. ${ }^{9}$

This was not the first clandestine flight to take place carrying political abductees, nor the first time that such orders had been carried out - but it was the first occasion on which a member of the armed forces had confirmed what had previously only been reported by human rights organisations.

Four years later, in 1999, former sergeant Víctor Ibáñez ${ }^{10}$ made a similar statement, which was published in a book by the journalist Fernando Almirón. His account describes the process leading up to these flights, and how the prisoners were conveyed to the aircraft. ${ }^{11}$ This declaration provided further confirmation that the 'death flights', part of the dictatorial machinery of disappearance, did in fact take place.

For this mechanism of disappearance to work, it was crucial that the ultimate 
fate of the bodies of the disappeared remained an absolute secret. Their sudden reappearance seemed to challenge and resist this silence, as the evidence of the atrocities committed was marked plainly upon them.

\section{The No Names of the Uruguayan coast}

\section{Department of Colonia}

The department of Colonia lies in the south-east of Uruguay, separated from Buenos Aires, Argentina by the Río de la Plata estuary. Eleven bodies in total, later buried as NN, were discovered along its coastline. The first body appeared in 1975, the last in 1978, ${ }^{12}$ and the remaining nine over the course of 1976. Eight of the victims, all male, were buried in Colonia's municipal cemetery, but contrary to regulations they were never disinterred for transfer to a common ossuary. This would allow the remains to be exhumed, years later, by the EAAF.

There were a number of similarities in the conditions in which the victims were found: most were tied at the hands and/or feet with the kind of cord used in window blinds, or had wires or cables around their waists. Furthermore, the labels on their clothes suggested that they had been bought in Argentina. All of the bodies bore clear signs of violence: they had multiple fractures, some of them fatal, and they had suffered beatings, ruptures and sometimes castration before being hurled into the water.

A general description, taken from various archives and autopsy protocols, of the bodies found in Colonia in 1976 is outlined below:

\section{- 3 January 1976}

Cause of death: According to the medical certificate signed by the medical examiner, Senior Inspector Luis Raimondi, the cause of death was asphyxia due to drowning. No further details are given. The body is described as being in an advanced state of decomposition. ${ }^{13}$

Method of identification: The remains were exhumed in 2002 by the EAAF. Bone samples were taken for DNA testing, which yielded no results. Following further analysis, in 2011 the remains were taken to Argentina, where it was hoped the victim could be identified.

No matches have been found to date in the EAAF's genetic database.

- 17 May 1967

Cause of death: The protocol of the autopsy performed by Senior Inspector Luis Raimondi indicates that: 'The body belongs to an individual who was subjected to severe physical abuse before being thrown into the water. A concrete block weighing approximately seven kilograms was tied to the waist with rope and wire.' ${ }^{14}$ The cause of death is omitted from the death certificate, which simply states: 'Autopsy to be carried out in accordance with the pending medical certificate. ${ }^{\text {'5 }}$ Method of identification: The remains were exhumed in 2002 by the EAAF. Bone samples were taken for DNA testing, which yielded no results. Following further analysis, in 2011 the remains were transported to the Republic of Argentina, where it was hoped the victim could be identified. 
In 2011, the body was confirmed to be that of Roque Orlando Montenegro Roldán (an Argentine national).

- 19 May 1976

Cause of death: The protocol of the autopsy performed by Senior Inspector Luis Raimondi indicates that: 'Wire has been tied around the body's waist. The feet are held together by two separate ties, one made out of cables and one of wires. [There are] multiple traumatic injuries [various fractures are described] and tearing to the anal and perianal region. ${ }^{16}$ The cause of death was found to be: 'Asphyxia due to drowning following multiple trauma.'17

Method of identification: The remains were exhumed in 2002 by the EAAF. Bone samples were taken for DNA testing, which yielded no results. Following further analysis, in 2011 the remains were transported to the Republic of Argentina, where it was hoped the victim could be identified. No matches have been found to date in the EAAF's genetic database.

- 26 May 1976

Cause of death: The protocol of the autopsy performed by Senior Inspector Luis Raimondi indicates that: 'The body is in an advanced state of decomposition, making a detailed autopsy examination difficult. No evidence of violence was found. ${ }^{18}$ The corresponding entry in the burial records at Colonia's municipal cemetery lists the cause of death as: 'Asphyxia due to drowning.' The cause of death is omitted from the death certificate: 'Autopsy to be carried out in accordance with the pending medical certificate.' 19

Method of identification: The remains were exhumed in 2002 by the EAAF. Bone samples were taken for DNA testing, which yielded no results. Following further analysis, in 2011 the remains were transported to the Republic of Argentina, where it was hoped the victim could be identified. No matches have been found to date in the EAAF's genetic database.

- 5 June 1976

Cause of death: The medical examiner who performed the autopsy was Dr Luis García Rivas. The cause of death is listed as 'strangulation' ${ }^{20}$

Method of identification: No documentation is available regarding the provenance of the body. In the Special Information Report compiled by the Colonia police in 1985 it is stated that the body of Raúl Antonio Niño was examined by the Argentine Deputy Naval Prefect of Guazusito and the Naval Prefect of the island of Marín García, and repatriated in an aircraft belonging to the Argentine Air Force. ${ }^{21}$

- 4 September 1976

Cause of death: The examination certificate issued by the local Justice of the Peace describes: 'two perforations, apparently caused by bullets ... A blow to the right side of the occipital region, compound fractures to both legs, various tearing injuries, removal of the genital organs, probably with a sharp instrument ... ${ }^{\prime 22}$ The protocol of the autopsy performed by Senior Inspector Luis Raimondi indicates that: "[The victim] has been bound by the hands and feet using curtain tape and there are multiple fractures ... the scrotal sac and its contents are missing; it cannot be determined whether this was the result of 
castration or the action of river fauna. ${ }^{23}$ The cause of death was not established and the death was never registered.

Method of identification: The remains were exhumed in 2002 by the EAAF. Bone samples were taken for DNA testing, which yielded no results. Following further analysis, in 2011 the remains were transported to the Republic of Argentina, where it was hoped the victim could be identified. No matches have been found to date in the EAAF's genetic database.

- 5 September 1976 (8.00 a.m.)

Cause of death: On his initial inspection of the body, Dr Juan C. Rossel stated that: '[The body] presents a lower third fracture of the left thigh bone ... There is a cut above the upper section of the scrotum, and both testicles and the scrotum have been ablated with a cutting instrument ...' He noted that the body appeared to have been thrown into the water after death. ${ }^{24}$

The report of the autopsy performed by Senior Inspector Dr Luis Raimondi does not specify the cause of death, but indicates: 'Collapsed skull with fracture to the right side of the occipital and parietal bones. The hands and feet are tied with curtain tape, and there are fractures to the left lower leg and thigh bone ...' It could not be determined whether or not the absence of the scrotal sac was the result of the action of river fauna. ${ }^{25}$ No record of a death certificate can be found.

Method of identification: The remains were exhumed in 2002 by the EAAF. Bone samples were taken for DNA testing, which yielded no results. Following further analysis, in 2011 the remains were transported to the Republic of Argentina in the hope of identifying the victim.

The body was identified in 2011 as that of Horacio Adolfo Abeledo Sotuyo (an Argentine national).

- 5 September 1976 (9.30 a.m.)

Cause of death: On his initial inspection of the body, Dr Juan C. Rossel noted fractures to the skull and the right leg and a suspected upper third fracture to the right hip. He observed the presence of pieces of thick roller-blind tape around both wrists, and two strips of fabric that had been rolled up and knotted around the victim's neck. As in the previous case, Dr Rossel stated with certainty that the victim had died before being thrown into the water. ${ }^{26}$

The report of the autopsy performed by Senior Inspector Dr Luis Raimondi describes a number of fractures but does not specify the cause of death. ${ }^{27}$

Method of identification: The remains were exhumed in 2002 by the EAAF. Bone samples were taken for DNA testing, which yielded no results. Following further analysis, in 2011 the remains were transported to the Republic of Argentina, where it was hoped the victim could be identified. No matches have been found to date in the EAAF's genetic database.

- 8 September 1976

Cause of death: On his initial inspection of the body, Dr Juan C. Rossel stated that the wrists had been tied very tightly, and noted a 'middle third fracture to the left arm.' ${ }^{28}$

In this case, the autopsy protocol completed by Senior Inspector Dr Luis 
Raimondi has not been recovered, and the only known record is a description of the verbal report relayed to the Naval Prefecture in Colonia: 'The cause of death was not asphyxia due to drowning; rather, the victim may have been beaten to death before being thrown into the water. ${ }^{29}$

Method of identification: The remains were exhumed in 2002 by the EAAF. Bone samples were taken for DNA testing, which yielded no results. Following further analysis, in 2011 the remains were transported to the Republic of Argentina, where it was hoped the victim could be identified. No matches have been found to date in the EAAF's genetic database.

\section{The conveyance and preservation ${ }^{30}$ of the bodies}

Once the discovery of the bodies had been reported, personnel from the National Naval Prefecture or the local Sub-prefecture, and occasionally the local Justice of the Peace, would attend the scene. The military authorities were responsible for compiling an initial report for the Justice of the Peace. This would eventually be referred to the Departmental Judge, who would open the corresponding investigation. The bodies were taken to the morgue, where the local medical examiner would perform the appropriate autopsy, or carry out an inspection of the body if an autopsy was not possible. At that point, fingerprints would be taken and sent to the National Directorate of Judicial Police in the department of Montevideo. Other items found with the body (clothes, documents, pieces of rope etc.) would also be sent to the Judicial Police.

A number of irregularities can be identified in this process: the Justice of the Peace, who had oversight of the civil register, was responsible for registering the deaths. This was supposed to be done only once a medical death certificate had been issued, and only when the deaths had been officially registered was burial authorised to take place. In many of these cases, however, the bodies were buried despite no such document having been produced, as the entries recorded by the Civil Registry Office show. These do not specify the cause of death, stating only: 'Autopsy to be carried out in accordance with the pending medical certificate.' This documentation was then sent to the local cemetery so that the bodies could be buried as NN. Seven of them were interred without any death certificate having been issued, although this was expressly prohibited under the regulations in force at the time.

In another case (the bodies found on 5 September 1976), the Justice of the Peace delayed referring the matter to the higher authority of the Departmental Judge for approximately one month, at the request of the Naval Sub-prefecture in Juan Lacaze (Colonia):

I waited about a month before passing on the file, at the express request of the Juan Lacaze Sub-prefecture. I had asked them to intensify their efforts to identify the bodies, because on one of them, or rather, in the clothes belonging to one of them, an Argentine identity card had been found. The card was completely legible and belonged to a woman with the surname of Cámpora ... That, to my mind, should have made it possible ... to find out something about this body or who it belonged to. I made the calls myself, in both the local and departmental prefectures, and after 
receiving no reply whatsoever, I sent the file on to the judge, as the allotted time had expired. About two months later, I received a letter from the district court in Rosario asking me whether the deaths had been officially recorded in the civil register, to which I immediately replied that they had not. I did not know until this moment that the deaths had never been registered. ${ }^{31}$

Furthermore, workers from the municipal cemetery in Colonia stated that the order to bury the bodies was issued verbally by the medical examiner to the head of the cemeteries department, ${ }^{32}$ and that no documentation of any kind was supplied. ${ }^{33}$

The bodies were transported to the cemetery morgue by a local undertaker, where the medical examiner (who was responsible for authorising burial) would be waiting along with personnel from the departmental Judicial Police and the Naval Prefecture. The remains would then be interred.

According to regulations amended in 1980 but still in force at this time, if a body had been buried for more than five years without anyone coming forward to claim it, the remains were to be disinterred and taken to a common ossuary. However, in this case the ordinance was not observed, and officials in charge of the cemeteries department retained the bodies in their original graves, although they risked punishment should their actions be discovered.

Because the remains were protected in this way, it was later possible for them to be exhumed and for DNA analysis to be carried out. The victims could not have been identified in any other way, since in most cases the bodies had not been fingerprinted.

\section{Department of Rocha}

The department of Rocha is located in the south-east of Uruguay, on the Atlantic coast. Over the course of 1976 and into early 1977, seven bodies were washed up on its shores and later buried as NN. As with the bodies found in Colonia, the NN discovered in Rocha shared certain characteristics, showing similar evidence of violence and being tied by the hands and/or feet.

A general description of the bodies found in Rocha is outlined below.

\section{- 22 April 1976}

Cause of death: The report of the local Justice of the Peace indicates the presence of bruising and other injuries, fractures to both arms and multiple bruises to the face, which was covered with a bandage: '[The victim was beaten] savagely, killed, and then thrown in the water. ${ }^{34}$ The police doctor, Dr Katz, performed a clinical examination (there was no autopsy), stating that the body belonged to an 'individual of oriental extraction'. ${ }^{35}$ The report also describes the presence of 'multiple abrasions and number of wounds, both deep and superficial, in both shoulders; a great many bruises, [and] fractures to both arms. The upper section of the face was pinched tightly by a wide bandage ... which, once removed, revealed a number of deep lesions ... Significant oedema of the scrotum and limbs ... ${ }^{36}$ Method of identification: On 26 April 1976 personnel from the Montevideo 
branch of the Judicial Police reported to the cemetery to fingerprint the body, which had not yet been identified. The remains were disinterred in 1983, and in 1986 they were transferred to a common ossuary. In 2012, fingerprint analysis identified the body as belonging to Nelson Valentín Cabello Pérez (a Chilean national).

\section{- 22 April 1976}

Cause of death: The police doctor, Dr Katz, examined the body: 'There are traumatic injuries to the facial bones, lower jaw, molars, and nasal bones. The veins, arteries, and tendons in the lower limbs have been destroyed - evidence of the brutal force exerted by the bonds. ${ }^{37}$ No autopsy was performed, and the death was recorded as being: 'the result of traumatic injuries ... the body was later thrown into water'. ${ }^{38}$

Method of identification: Unidentified. No fingerprints were taken due to the 'advanced state of decay'. ${ }^{39}$ The remains were disinterred in 1983, and in 1986 they were transferred to a common ossuary.

- 22 April 1976 (female)

Cause of death: The police doctor, Dr Katz, carried out a clinical analysis (no autopsy was performed). Dr Katz noted indications of rape, multiple fractures to the left arm ... The bones of both legs have been shattered, and show evidence of having been tightly bound ... Massive bruising ... The skull has been completely crushed, and a very large, irregular opening in the occipital region can be observed ... Death was caused by multiple violent trauma that effectively destroyed the victim's body. ${ }^{30}$

Method of identification: On 25 April personnel from the National Directorate of Judicial Police (Montevideo) fingerprinted the body and subsequently endeavoured to identify the victim, without success. ${ }^{41}$

The remains were disinterred in 1983, and in 1986 they were transferred to a common ossuary. In 2012, fingerprint analysis identified the body as belonging to Laura Gladis Romero (an Argentine national).

- 23 April 1976 (7.00 a.m.)

Cause of death: The clinical examination carried out by Dr Katz indicates: 'multiple bruises, arms tied behind the back, and the head completely destroyed ... The victim was violently killed as a result of the brutal trauma to which he was subjected ...' ${ }^{42}$

Method of identification: Unidentified. No fingerprints were taken due to the 'advanced state of decay'. ${ }^{43}$ The remains were disinterred in 1983, and in 1986 they were transferred to a common ossuary.

- 23 April 1976

Cause of death: The clinical examination carried out by Dr Katz indicates: '1) Shattering of the skull and facial bones... Severe damage to the anal and inguinal region due to very extensive traumatic injuries. Injuries to the bones with multiple fractures to all four limbs. The lower limbs show signs of having been bound [and the hands were tied with wire]. Death ... was the result of the savage trauma evident from the condition of the body ..." ${ }^{34}$

Method of identification: Unidentified. The body was fingerprinted by officers 
from the National Directorate of Judicial Police. To date, no matches have been found to allow the victim to be identified.

The remains were disinterred in 1983, and in 1986 they were transferred to a common ossuary. In 2012, fingerprint analysis identified the body as belonging to Luis Guillermo Vega (an Argentine national).

- 1 May 1976

Cause of death: An autopsy examination was performed by Dr Jesús Laborda from the police health services. The report indicates: '[The body] presents a number of bruises in the dorsal region and on the right leg ... the left hand is tied with a nylon cord and there is a further strip of canvas binding the right supramalleolar region ... The body is that of an Asian male ...' No cause of death was recorded. ${ }^{45}$

Method of identification: The body was fingerprinted by officers from the Rocha branch of the Judicial Police.

The remains were disinterred in 1983, and in 1986 they were transferred to a common ossuary. The victim was identified from fingerprint records in 2012 as Luis Guillermo Vega Ceballos (a Chilean national).

\section{The No Names from the Far East: the public display of the bodies}

The five bodies discovered in April 1976 provoked alarm and consternation among the general population, forcing the authorities to provide some sort of explanation. They began to construct a narrative alleging that the bodies belonged to Asians, probably crew members from a ship originating in more eastern latitudes. ${ }^{46}$

Pressure at both local and national levels continued to mount, precipitating a press conference that was held at the local cemetery, inside the morgue itself, on 24 April, 1976. Presiding over the proceedings was the medical examiner, Dr Mario Katz. As well as showing the bodies to those in attendance, he described their condition in the following terms:

We will be showing you the bodies openly. Look, this is the body of a woman; ${ }^{47}$ as you can see her face has been completely destroyed, and in the upper section it has collapsed, as has the base of the skull; the body is in an extreme state of decomposition; as you see there is a complete fracture to this limb; look, you will see that the bones from this point down are broken, and those on the other side as well. She was firmly tied up and now you see all of this bruising and ecchymosis all over the body. Furthermore, the victim was raped. Now as you can see from the face and the typical features of the body, this woman was undoubtedly from one of the countries of the Far East ... Everything we find with this body you will see repeated in all the others as well: a huge number of bruises, broken facial bones, fractured skull, broken bones; and something else that is striking is the complete absence of any foam fungus, indicating that this woman was killed before she was put in the water. ${ }^{48}$

The press conference continued along these lines, with the doctor pointing out the various broken bones and exposing the bodies to the gaze of all those present, so that they became eye-witnesses to the violence unleashed on the victims. 


\section{Magdalena Figueredo and Fabiana Larrobla}

This is body number two ... Look at all these signs of injury; there are broken bones in both the upper and lower limbs, the facial bones have collapsed, as you can see ... If we look at it from the other side, the skull is fractured, the hands and feet ... We saw this the day before yesterday, and again we can say that this individual is of oriental extraction. Now look, this is body number one, which we have already seen, you can tell by looking at it that it has similar injuries to the rest ... and you can see from the face that this person is Chinese or of some similar race; of course, the facial features are completely impossible to inspect because the skull is totally destroyed, but the general appearance, the complexion of the victim, suggests that she belonged to the same race as the others we have examined ... the victims were brutalised before they were killed.

Question from a journalist: the male victims as well?

Dr Katz answers: Yes, yes, yes, they were brutalised ... according to the full examination that we carried out yesterday, the victims were brutalised before they were killed $\cdots$

Question from a journalist: Is it possible ... to tell whether these people were drug addicts or anything like that?

Dr Katz answers: It is very difficult to make that kind of assessment; what is evident is that all of these individuals were savagely murdered in a way that is fortunately unheard of in this part of the world. ${ }^{49}$

From the partial transcription of the press conference, we can get a sense of the manner in which the bodies were exposed to the public eye; neither the details of the torture inflicted upon the victims nor the allusions to the abuse that they suffered seem to evoke any sense of horror. Rather, the incident served as a reiteration of the torture, a new display of dictatorial power, this time projected upon the bodies of the dead.

The state's insistence on the purported East Asian origins of the NN was an attempt to conceal the truth of these events, and to displace the atrocities far from the place where they had really occurred. It sought to distance the victims not spatially (in any case it was clear that they met their deaths in the waters of the Río de la Plata or the Atlantic Ocean) but culturally, creating a fundamental divide between a 'them' and an 'us'. The machinery of disappearance forged in Argentina also implicated the Uruguayan state, which perpetuated it and reinforced it through a number of different strategies aimed at preserving the secret.

\section{Who were the No Names?}

Even before any of the bodies could be identified, various clues and tokens somehow slipped through the web of deceit and disinformation to give rise to speculation about the true provenance of the bodies. 
A study carried out by Estela Schindel describes some of these early indications: in May 1976 it was reported that 'the Uruguayan authorities have confirmed that another body - the eleventh to be found since 24 April this year - has appeared off the coast of Colonia, and that money and personal effects from Argentina were found with it'. The strange appearances continued, and the Argentine newspaper La Nación observed that 'the macabre discoveries of mutilated bodies, naked and with their hands tied, which began last month when five corpses were found in a single day in the waters to the east of Montevideo, have given rise to all sorts of speculation as to the identity of the victims and why they were killed'. This 'speculation', which 'La Nación will not repeat, has led to a complex web of interpretations and guesswork: it was reported that the eighth body had a tattoo identical to one described in a writ of habeas corpus, clearly demonstrating to anyone who might care to read it that the bodies found in Uruguay belong to individuals who disappeared in Argentina'. ${ }^{50}$

The allegations made by Rodolfo Walsh in his letter of 1977, mentioned earlier, demonstrate the public's dismay at these crimes. As Crenzel observes, they provide us with an early indication that: 'The dictatorship's strategic decision to forbid the disclosure of any information relating to the discovery of the bodies, and to conceal the bodies themselves following the mass murder of both clandestine and legal detainees, [was] the final link in the chain of secrecy and silence that was wrapped around the disappearances. ${ }^{51}$

The legitimacy of these claims and rumours, which continued to circulate as an 'open secret' for many years, was recognised only after democracy had been restored, and answers to the remaining questions surrounding these victims slowly began to emerge.

In Uruguay, from $1985^{52}$ onwards, investigative commissions were set up by the Departmental Board of Colonia. Meanwhile, the Investigative Commission on the Situation of Disappeared People and its Causes was established by the country's Parliament. Allegations were also brought before the courts by the human rights organisations Peace and Justice Service (SERPAJ) and the Latin American Federation of Associations for Relatives of the Detained-Disappeared. These legal investigations opened up access to a range of documentation pertaining to these events.

Although this constituted a significant step forward in the search for the truth, it was only after 2000, with the establishment of the Peace Commission, that substantial action was taken towards identifying the NN. In conjunction with the EAAF, information was requested from the various departmental authorities, in this case in Rocha and Colonia, and, as this arrived, efforts to identify the bodies were able to progress.

In Colonia, the bodies of the victims were exhumed in 2002 and an autopsy examination was carried out in each case. In 2003, Uruguay's National Directorate of Judicial Police became involved and it carried out the first DNA analyses, although there were no samples to which DNA taken from the bodies could be compared. Eventually, in 2010, the EAAF asked the government of Uruguay for authorisation to carry out a parallel investigation on the remains exhumed in 2002. 
They were taken to Argentina where, as a result of the widening of the various investigations and the collation of DNA samples, two victims were identified by the close of 2011. They were Horacio Adolfo Abeledo Sotuyo and Roque Orlango Montenegro Roldán.

Abeledo Sotuyo, Horacio Adolfo. Argentine citizen, born 25 July 1953. Abducted 21 July 1976, aged almost 23, from 2027 Avenida Belgrano, Buenos Aires, Argentina. An anthropology student, he was an active member of the Workers' Revolutionary Party (PRT). His body was found on 5 September 1976.

Montenegro Roldán, Roque Orlando. Argentine citizen, born 16 August 1955. Abducted at the age of 20 on 13 February 1976, along with his wife, Hilda Ramona Torres (who has never been found), and his 13-day-old daughter, Victoria Montenegro. The child was taken in by Coronel Hermann Tetzlaff, who was stationed in the Campo de Mayo military base, and recovered her biological identity on 5 July 2000. Roque Montenegro was active in the People's Revolutionary Army (ERP). His body was discovered on 5 May 1976.

In 2001 the Peace Commission learned that the remains buried in Rocha could not be exhumed, as they had been removed from their graves in 1983 and transferred to a common ossuary three years later. Fingerprints had been taken from only four of the seven bodies, three of which could now be identified.

In all four cases, fingerprint analysis was carried out with the support of the Uruguay Forensic Investigation Institute, a specialist team from the Argentine Naval Prefecture's Expert Scientific Department and the EAAF. The three victims identified as a result of this process were Nelson Valentín Cabello Pérez, Laura Gladis Romero Rivera and Luis Guillermo Vega Ceballos.

- Cabello Pérez, Nelson Valentín. Chilean citizen, born 8 October 1953. Abducted 9 April 1976, at the age of 23, in the city of Valentín Alsina (Buenos Aires Province, Argentina). His wife and brother-in-law are presumed to have been abducted at the same time, but have never been found. He was active in the Workers' Revolutionary Party (PRT). His body was found on 22 April 1976.

- Romero Rivera, Laura Gladis. Argentine citizen, born 29 December 1956. Abducted 9 April 1976, when she was 19 years of age and four months pregnant, along with her partner, Luis Guillermo Vega Ceballos. The couple were seized at their home in Calle Olavarría (Argentina). Her body was found on 22 April 1976.

- Vega Ceballos, Luis Guillermo. Chilean citizen, born 18 September 1947. Abducted at the age of 29, on 9 April 1976, with his partner Laura Gladis Romero Rivera. The couple were seized from their home in Calle Olavarría (Argentina) by uniformed personnel from the Argentine army. His body was found on 22 April 1976.

\section{Conclusions: Uruguay's complicity in the state cover-up}

The discovery of the bodies gave rise to much speculation and a range of questions about the version of events that the authorities offered to the press. Accusations 
voiced from abroad, by exiles of the dictatorships in both Argentina and Uruguay, suggested the possibility that these bodies could belong to civilians who had been abducted and whose whereabouts were now unknown. When the victims were eventually identified, these initial conjectures were confirmed - and one of the most abhorrent practices of the dictatorial circuit of repression finally came to light.

The No Names formed one of the most shocking components of the circuit of repression designed to bring about the total death of the individual; total death, in the sense that the regime endeavoured to eliminate every space in which the dead continued to exist, including their physical burial place and the mental spaces where their memory was preserved. ${ }^{53}$

The bodies that were dumped in the water thwarted this total death by emerging from the sea and challenging the dictatorships that sought to make them disappear. News of the discoveries spread beyond the local area, prompting new searches as well as accusations levied at an international level. The horrors secretly perpetrated by the two states in order to spread fear among their populations were made public through the evidence written on the bodies themselves. In this way, the appearance of the corpses on Uruguay's shores threatened to unveil the state's repressive agenda of total annihilation, as those who had been 'disappeared' 'reappeared' for all to see. The secrecy of this agenda, essential to the continued functioning of the machinery of disappearance, ${ }^{54}$ was called out from the very silence of death by the same bodies that were supposed to have vanished and to lie hidden and forgotten.

In turn, this machinery extended to and implicated the dictatorial regime in Uruguay, and this complicity offers us new avenues for exploring how the various organs of the two states were able to coordinate and interlock as Operation Condor was rolled out. ${ }^{55}$

As a general rule, when we think about internationally coordinated repression, what come to mind, almost exclusively, are the acts of violence perpetrated by intelligence services in some foreign country, and by the intelligence services of foreign countries on our own soil, or else the illegal transport of civilians. The events described here confront us with different mechanisms; mechanisms that require the collusion of one state, Uruguay in this case, with the crimes committed by another, and the willingness of that state to actively participate in covering up those crimes.

A review of the available documentation, passages of which have been cited here, reveals how quickly the mechanisms employed to exert pressure on the various actors swung into action in each setting, to ensure that the bodies were buried despite the fact that the statutory protocols had not been followed. The Uruguayan state acted to cover up the facts and to curb any subsequent investigation, and, when necessary, it enlisted medical authority to legitimise the narrative that the bodies belonged to some Eastern race. Although such strategies of misrepresentation and dissimulation have long been employed by dictatorial regimes to cover up their own crimes, or those in which they were active participants, what seems unusual in this case is the idea that these same strategies were brought to bear by the Uruguayan dictatorship in order to support and protect the fundamental secret 
underlying Argentina's system of disappearance; a system based on the three stages of abduction, murder and clandestine disposal of the bodies. ${ }^{56}$

As Pilar Calveiro observes, 'The NN are not an epilogue; they are one of the central chapters of this story. If disappearance was the linch-pin of the repressive order, precisely so that "no one would find out," one of the means through which it was perpetrated were the techniques used to secretly abduct the victims and destroy their bodies.'

The reappearance of the bodies and their subsequent identification subverted the designs of the tactic of disappearance, unveiling the atrocities that were being committed and allowing us to reconstruct, at least in some small measure, one part of this 'sequestered and vanished story'.

The NN are part of the evidence, the human remains that bear witness to the fact that the disappeared did not vanish into thin air but were executed. These skeletons can be identified to allow us to piece together a story; the story of a person with a name and a family, who disappeared on a specific day from a specific place ... the remains of the NN are evidence of a crime, and where there is a crime there is a criminal. In other words, their remains make a claim on our collective conscience, circumventing our amnesia and forcing us to contemplate the concentration camp: that state-instituted crime, that nefarious governmental enterprise that is crying out for punishment. ${ }^{57}$

\section{Notes}

Translated from authors' Spanish by Candenza translation

1 Two further bodies were found in the department of Colonia (in 1975 and 1978), three in Maldonado, nine in Montevideo and two in Rocha (1977 and 1979).

2 The term 'NN' is derived from the Latin 'nomen nescio', meaning 'I do not know the name'. In Spanish, it is typically used as shorthand for 'Ningún Nombre' (No Name). In Uruguay, $\mathrm{NN}$ is used to designate bodies belonging to unknown individuals, and the term appears in entries in cemetery record books. It is also sometimes used in relation to living persons whose identity is unknown. Here, we have followed the practice of the various documentary records of the time, which refer to these bodies as ' $\mathrm{NN}$ ', and adopted the full term as it is used in Spanish: the No Names.

3 J. López Mazz, 'Una Mirada arqueológica a la represión política en Uruguay', in P. P. Funari and A. Zarankin (eds), Arqueología de la represión y la resistencia en América Latina (Córdoba, Encuentro Grupo Editor, 2006), pp. 147-59.

4 J. López Mazz, 'The Concealment of Bodies during the Military Dictatorship in Uruguay (1973-1984)', in Élisbeth Anstett and Jean-Marc Dreyfus (eds), Human Remains and Identification (Manchester, Manchester University Press, 2015), pp. 83-98.

5 Rodolfo Walsh was abducted on 25 March 1977, one day after sending copies of his open letter to the military junta through the post. He has never been found.

6 The body of Floreal Avellaneda, who was abducted in Buenos Aires province on 
15 April 1976 and then disappeared, was found on the coastline at Montevideo on 14 May of the same year. He was buried in the Uruguayan capital's Cementerio del Norte on 15 May 1976 and, following an article that appeared in an Argentine newspaper, a relative began to look into the circumstances of his death. This investigation ultimately led to the identification of his remains on 3 September 1977. His body was never reclaimed.

7 Open letter from Rodolfo Walsh to the Argentine military junta, Buenos Aires, 24 March 1977.

8 Horacio Verbitsky, Argentine journalist and author, president of the Centre for Legal and Social Studies (CELS) in Argentina.

9 H. Verbitsky, El Vuelo (Buenos Aires, Planeta, 1995), p. 16.

10 Ibáñez had been in charge of logistics and looking after prisoners in the Campo de Mayo Secret Detention Centre between 1976 and 1980.

11 'They injected the prisoners one by one as they arrived by the plane. Afterwards, they went up four or five of the aircraft steps and immediately began to feel unwell. Two other guys and I would be waiting for them up at the top. We would guide them to where they had to sit, but before they had time to settle down, the pains would start ... I don't know what that drug did to them, but in less than a minute they already looked like corpses ...'. F. Almirón, Campo Santo - los asesinatos del ejército en Campo De Mayo. Testimonio del ex-sargento Víctor Ibáñez (Buenos Aires, Colección Política, 1999), www.desaparecidos.org/nuncamas/web/investig/ almiron/cposto/cposto24.htm.

12 In neither of these two cases were fingerprints taken; the bodies were buried as NN and the remains were later transferred to the common ossuary. The body found in 1975 was dressed in clothes identified as coming from Argentina.

13 Archives of the Human Rights Secretariat for the Recent Past (SDDHHPR).

14 Autopsy protocol from the file entitled 'Investigaciones de la I.M. Colonia', archives of the SDDHHPR.

15 Ibid.

16 Autopsy protocol dated 19 May 1976, archives of the SDDHHPR.

17 Ibid.

18 Autopsy protocol dated 26 May 1976, archives of the SDDHHPR.

19 File entitled 'Investigaciones de la I.M. Colonia', archives of the SDDHHPR.

20 Presidencia República Oriental del Uruguay, 2015, Actualización de la Investigación Histórica sobre Detenidos Desaparecidos. Sección N.N., Section Five: 'N.N. aparecidos en costas uruguayas.' En: www.sdh.gub.uy.

21 Ibid.

22 Examination certificate, 4 September 1976, archives of the SDDHHPR.

23 Autopsy protocol, 6 September 1976, archives of the SDDHHPR.

24 Public Health Service Report, 5 September 1976, archives of the SDDHHPR.

25 Autopsy protocol, 6 September 1976, archives of the SDDHHPR.

26 Public Health Service Report, 5 September 1976, archives of the SDDHHPR.

27 Autopsy protocol 6 September 1976, archives of the SDDHHPR.

28 Report to the police authorities of Colonia, 8 September 1976 archives of the SDDHHPR. 
29 Official communication to the Head of the Technical Corps of the National Judicial Police, 9 September 1976, archives of the SDDHHPR.

30 We use the word 'preservation' here to refer to the retention of the bodies in the place where they were originally buried, which went against regulations stipulating that the remains should be disinterred and transferred to a common ossuary.

31 Blanca Germana, Justice of the Peace of the 14th Judicial Division of Colonia, testimony before the District Court of Colonia, 19 February 1987, archives of the SDDHHPR.

32 Cemeteries in Uruguay fall under the management of specific local government agencies in each department - in Colonia's case, this is the Directorate of Cleanliness, Health and Cemeteries.

33 Statement by cemetery employee Mr Luis Alberto Vida to the District Court of Colonia, 6 November 1985, archives of the SDDHHPR.

34 Certificate of Acknowledgement, 22 April 1976, file number 272/1977, archives of the SDDHHPR.

35 Report of the examination of unidentified bodies, file number 272/1977, archives of the SDDHHPR.

36 Ibid.

37 File number 272/1977, archives of the SDDHHPR.

38 Ibid.

39 National Directorate of Judicial Police, archives of the SDDHHPR.

40 Report by Dr Katz, file number 272/1977, archives of the SDDHHPR.

41 National Directorate of Judicial Police, archives of the SDDHHPR.

42 Report by Dr Katz, file number 272/1977, archives of the SDDHHPR.

43 National Directorate of Judicial Police, archives of the SDDHHPR.

44 Report by Dr Katz, file number 272/1977, archives of the SDDHHPR.

45 Autopsy report dated 2 May 1976, file number 272/1977, archives of the SDDHHPR.

46 Fishing boats from China and Korea frequently operate off the coast of Uruguay, providing a plausible argument for the nationality of the victims.

47 The woman that Dr Katz was talking about was later identified as Laura Romero.

48 Update from the Historical Investigation on Disappeared Detainees, NN Section, accessed at www.sdh.gub.uy.

49 Ibid.

50 E. Schindel, 'Desaparición y sociedad. Una lectura de la prensa grafica argentina (1975-1978)', thesis, Free University of Berlin, 2003, p. 137.

51 E. Crenzel, 'Cartas a Videla: una exploración sobre el miedo, el terror y la memoria', Instituto Interdisciplinario de Estudios Latinoamericanos (IIELA), 2:2-3 (Facultad de Filosofía y Letras, Universidad Nacional de Tucumán, 2003), 41-57.

52 The first democratic government in Uruguay after the fall of the dictatorship was inaugurated on 1 March 1985.

53 J. Chaves, 'Cuerpo, Poder y Territorio en rituales y prácticas funerarias del conflicto armado colombiano: un análisis antropológico de algunos municipios en Caldas y Risaralda', Revista Eleuthera 4 (Revista Iberoamericana de Desarrollo Humano y Social, Departamento de Desarrollo Humano de la Facultad de 
Ciencias Jurídicas y Sociales, de la Universidad de Caldas, Enero-Diciembre 2010), 230-49.

54 P. Calveiro, Poder y desaparición: los campos de concentración en Argentina (Buenos Aires, Colihue, 2004), p. 78.

55 The Historical Investigation on Disappeared Detainees reported a number of facts that support the existence of various forms of international coordination that began to operate in 1973 and 1974 - preceding Operation Condor. Patrice McSherry has traced the beginning of these operations back to the end of 1973, and cites Central Intelligence Agency evidence of a meeting held in Buenos Aires between police security personnel from Argentina, Chile, Brazil, Uruguay, Paraguay and Bolivia in February 1974. In November 1975 the various dictatorial governments in Latin America pledged their mutual support by signing the document that was to pave the way for the system of regional cooperation known as 'Condor'. The document was signed by representatives from Chile, Argentina, Uruguay, Paraguay and Bolivia. Brazil was involved in some of the coordination arrangements but was not a full participant in Operation Condor in the sense that the other signatory countries were. Presidencia República Oriental del Uruguay, Investigación Histórica sobre Detenidos-Desaparecidos (Montevideo, IMPO, 2007), p. 285.

56 Calveiro, Poder y desaparición, p. 77.

57 Ibid., p. 164. 